\title{
Ekonomi Kreatif Sebagai Solusi Alternatif Meningkatkan Daya Saing Di Era Digital
}

\author{
SITI SYAHSUDARMI \\ Sekolah Tinggi Ilmu Ekonomi Riau \\ Jln. H.R. Subrantas No.57 Panam Pekanbaru 28293 Telp (0761) 63237 \\ E-mail : sitisyahsudarmi@lecturer.stieriau-akbar.ac.id
}

\begin{abstract}
The rapid development of information and communication technology is currently able to encourage the growth of business activities entering the era of creative economy to be very elastic and dynamic in facing the challenges of globalization and modernization. This study uses a qualitative descriptive approach with a literature study method. The results of the analysis state that the creative economy is a manifestation of efforts to find a formula for sustainable development through ideas and creativity. The creative economy is an alternative solution to the welfare of society in improving the economy to become competitive.
\end{abstract}

Keywords: creative economic, competitiveness, digital era

Perkembangan teknologi informasi dan komunikasi (TIK) yang super cepat di era millennial saat ini mendorong semua lini kehidupan untuk dapat menyesuaikan dengan lingkungan yang dinamis. Secara natural perkembangan TIK dilakukan dalam rangka agar aktifitas diberbagai bidang menjadi praktis, efektif dan efisien sehingga dapat memaksimalkan sumber daya terutama human capital dalam meningkatkan produktifitas agar kinerja menjadi lebih baik, mengingat persaingan usaha saat ini mengalami pergeseran paradigm menuju kearah yang sebelumnya tata kelolanya masih bersifat konvensional, sebut saja analog, yang mengalami evolusi mengikuti perkembangan teknologi informasi beralih menjadi tata kelola yang bersifat up to date kontemporer yang bisa disebut dengan istilah digital yang berbasis ilmu pengetahuan dan teknologi (IPTEK) baik secara langsung maupun tidak langsung memberikan stimulus kreatifitas yang didukung dengan ragam media yang tersedia di dunia siber.

Era digital dalam TIK memungkinkan pertukaran informasi baik berupa suara, data, maupun video dapat ditransfer dalam hitungan detik dengan jangkauan global, yang seolah-olah dapat menembus ruang dan waktu yang tak berbatas. Digitalisasi ini dalam perspektif

Jurnal Daya Saing (Vol. 5, No. 1 Februari 2019) kegiatan usaha memberikan keuntungan yang besar, baik dari pihak penyelenggara dan penyedia jasa (provider) maupun pengguna (users/ subscribers). Menjadi keniscayaan bahwa yang mampu menguasai teknologi informasi dengan dukungan ide dan kreatifitas akan memiliki peluang yang lebih besar dalam memperoleh keuntungan mengingat potensi pasar yang sangat luas dengan permintaan yang sangat tinggi terhadap suatu produk (barang dan jasa), tidak hanya di dalam negeri tetapi mampu menjangkau dunia internasional (world wide).

Sejalan dengan era digitalisasi, beragam kegiatan usaha bermunculan dengan kreatifitas yang mengagumkan diberbagai bidang dengan memanfaatkan perkembangan teknologi informasi, seperti perdagangan, transportasi, perbankan, pendidikan, ekspedisi, perhotelan, beragam jasa bahkan pelayanan di pemerintahan pun berbasis digital. Pertumbuhan usaha dalam hal memanfaatkan perkembangan era digital seolah tidak bisa dibendung baik yang hanya memanfaatkan atmosfir siber dengan mengeksploitasi kreatifitasnya untuk mendapatkan manfaat dalam menjalankan usahanya maupun yang menciptakan produk atau jasa yang hidup

p.ISSN: $2407-800 \mathrm{X}$ e.ISSN: 2541-4356 
di habitat teknologi (techno preneurship), kedua bidang kegiatan ekonomi tersebut, dalam perspektif usaha sering disebut dengan istilah ekonomi kreatif.

Ekonomi kreatif adalah suatu konsep solusi alternatif untuk merealisasikan pembangunan ekonomi yang berkelanjutan berbasis kreativitas. Pemanfaatan sumber daya yang tidak hanya terbarukan, bahkan hampir tidak terbatas, yaitu ide, gagasan, bakat atau talenta dan kreativitas. Nilai ekonomi dari suatu produk atau jasa di era kreatif tidak lagi ditentukan oleh bahan baku atau sistem produksi seperti pada era industri, tetapi lebih kepada pemanfaatan kreativitas dan penciptaan inovasi melalui perkembangan teknologi informasi. Sehingga, industri tidak dapat lagi bersaing di pasar global dengan hanya mengandalkan harga atau kualitas produk saja, tetapi harus bersaing berbasiskan inovasi, kreativitas dan imajinasi (Afif, Faisal 2012 dalam Purnomo, 2016).

Ekonomi kreatif merupakan sistem transaksi (supply and demand) yang memiliki pengertian lebih luas daripada industri kreatif. Menurut Wikipedia, industri kreatif adalah a set of interlocking industry sectors that focus on creating unique property, content or design that previously did not exist. Sedangkan Department for Culture, Media and SportDCMS pemerintah United Kingdom (UK) memberikan definisi tentang industri kreatif sebagai as those industries which their origin in individual creativity, skill and talent, and which have a potential for wealth and job creation through the generation and exploration of intellectual property and content (industri yang berasal dari pemanfaatan kreativitas, ketrampilan serta bakat individu untuk menciptakan kesejahteraan serta lapangan pekerjaan melalui penciptaan dan pemanfaatan daya kreasi dan daya cipta individu tersebut). (Creative Industries Mapping Document, DCMS, 2001).
Para pihak yang berkecimpung dalam industri kreatif banyak mengacu pada definsi dari UK DCMS. Departemen Perdagangan Republik Indonesia ketika melakukan studi pemetaan industri kreatif (2007) juga menggunakan acuan definisi industri kreatif yang sama dengan UK DCMS. Pemerintah UK mengejawantahkan industri kreatif menjadi 11 subsektor, sedangkan pemerintah RI menetapkan 14 subsektor yang merupakan industri berbasis kreativitas. Berikut ini pembagian subsector industri kreatif menurut beberapa versi.

Menyimak berbagai konsep dan pengertian tersebut, secara realistissederhana ekonomi kreatif (creative economy) diartikan sebagai talenta (ide kreatif-inovatif) dengan nilai ekonomi yang mampu merubah kualitas hidup manusia menjadi lebih sejahtera. Ekonomi kreatif lebih mengandalkan kreativitas individu melalui gagasan, daya kreasi, dan daya cipta untuk meningkatkan nilai tambah ekonomi karyanya, sehingga mampu menciptakan lapangan kerja dan kesejahteraan.

Ekonomi kreatif dalam perspektif penyelenggaraan pemerintahan daerah idealnya dibangun dari ide-ide inovatif (innovation) yang mampu menstimulasi pertumbuhan ekonomi, bisnis, dan investasi (growing business), berorientasi daya saing menuju transformasi industri kreatif (competition), dan dapat meningkatkan kesejahteraan masyarakat (people welfare). Dalam konteks ini, pra kondisi diperlukan untuk: (1) identifikasi dan inventarisasi jenis dari 14 subsektor ekonomi kreatif di daerah; (2) membangun database; (3) merumuskan kebijakan, orientasi, target capaian, dan strategi pengembangan; (4) peningkatan kapasitas kelembagaan pengelola ekonomi kreatif di daerah; (5) menata prosedur, mekanisme, dan jaringan untuk pemasaran produk ke pasar domestik maupun mancanegara; (6) meningkatkan kompetensi sumberdaya manusia (SDM); 
(7) menjamin kualitas produk dan pelayanan pasca jual; dan (8) kelestarian lingkungan demi keberlangsungan usaha.

Persoalannya justru sejauhmana kreativitas masyarakat dunia usaha saat ini, Kreativitas merupakan talenta yang mampu membuahkan potensi besar dan mendukung keberlanjutan perekonomian individu, masyarakat, daerah, dan bahkan Nasional. Namun, sejauhmana "kreativitas" (ekonomi kreatif dan industri kreatif) mampu memicu daya saing daerah dan daya saing Nasional?

\section{METODE}

Metode penelitian yang digunakan dalam makalah ini adalah studi literatur. Berbagai literatur yang digunakan berupa jurnal-jurnal, $e$-book, portal berita dan bahan bacaan lain yang sesuai relevansinya dengan topik yang dibahas dalam makalah ini.

\section{HASIL}

Sebagai talenta baru, ekonomi kreatif diharapkan mampu menjadi pengungkit daya saing. Eksistensinya memerlukan pengakuan yang harus diwujudkan melalui berbagai regulasi/ kebijakan dan kebersamaan tindakan antara regulator, mediator, fasilitator, implementor, aktor, dan bahkan penerima manfaat lainnya (beneficiaries).

Secara manajerial, dalam perspektif sense of urgency, diidentifikasi 5 (lima) agenda pengembangan ekonomi kreatif yang memerlukan penataan dan pengelolaan secara paripurna. Kelima agenda tersebut, yaitu: (1) pemetaan kendala operasional; (2) upaya terobosan; (3) komitmen dan tindakan; (4) kesadaran masyarakat; dan (5) pentingnya basis data

Istilah Ekonomi kreatif berkembang dari konsep modal berbasis kreatifitas yang dapat berpotensi meningkatkan pertumbuhan ekonomi di suatu daerah. Menurut Presiden Susilo Bambang Yudhoyono dalam Agung Pascasuseno (2014), "ekonomi kreatif merupakan ekonomi gelombang ke-4 yang mana kelanjutan dari ekonomi gelombang ketiga dengan orientasi pada kreativitas, budaya, serta warisan budaya dan lingkungan".

Jo Foord (2008) menyatakan bahwa harus ada integrasi antara lembaga publik dan swasta dengan pertumbuhan perusahaan dan tujuan sosial yang semakin populer di tingkat kota di dalam pengembangan ekonomi kreatif. Kegiatan promosi dan dukungan pengembangan industri kreatif membutuhkan perencanaan strategis. Pada saat yang sama pertumbuhan lapangan kerja industri kreatif mulai tidak menentu di pusat kotakota industri kreatif sehingga dibutuhkan pengetahuan ekonomi yang lebih luas dan besar untuk mengatasinya

Ekonomi kreatif merujuk pada buku Pengembangan Ekonomi Kreatif Indonesia 2025: Rencana Pengembangan Ekonomi Kreatif Indonesia 2009-2015, yang diterbitkan oleh Kementrian Perdagangan RI merupakan era ekonomi baru yang mengintensifkan informasi dan kreativitas dengan mengandalkan ide dan stock of knowledge dari sumber daya manusianya sebagai faktor produksi utama dalam kegiatan ekonominya. Dengan kata lain, perhatian utama ekonomi kreatif adalah pada faktor human capital.

llmu pengetahuan (knowledge) dalam perekonomian modern memegang peranan yang paling penting. Masyarakat yang berkembang, maju secara peradaban dan memiliki kesejahteraan yang baik adalah masyarakat yang memiliki dasar pengetahuan ekonomi yang baik. Hal ini mutlak diperlukan, khususnya di Indonesia, yang perekonomiannya masih berkembang.

Mengutip dari Cetak Biru Ekonomi Kreatif 2025, ekonomi kreatif merupakan suatu penciptaan nilai tambah (ekonomi, sosial, budaya, lingkungan) berbasis ide yang lahir dari kreativitas sumber daya manusia (orang kreatif) dan berbasis pemanfaatan ilmu pengetahuan, termasuk warisan budaya dan teknologi. Kreativitas tidak sebatas pada karya yang berbasis seni dan budaya, namun juga bisa berbasis ilmu pengetahuan dan teknologi, engineering dan ilmu telekomunikasi. Terdapat 3 hal pokok yang menjadi dasar dari ekonomi 
kreatif, antara lain kreativitas, inovasi dan penemuan.

\section{a. Kreativitas (creativity)}

Dapat dijabarkan sebagai suatu kapasitas atau kemampuan untuk menghasilkan atau menciptakan sesuatu yang unik, fresh, dan dapat diterima umum. Bisa juga menghasilkan ide baru atau praktis sebagai solusi dari suatu masalah, atau melakukan sesuatu yang berbeda dari yang sudah ada (thinking out of the box). Seseorang yang memiliki kreativitas dan dapat memaksimalkan kemampuan itu, bisa menciptakan dan menghasilkan sesuatu yang berguna bagi dirinya sendiri beserta orang lain.

\section{b. Inovasi (innovation)}

Suatu transformasi dari ide atau gagasan dengan dasar kreativitas dengan memanfaatkan penemuan yang sudah ada untuk menghasilkan suatu produk ataupun proses yang lebih baik, bernilai tambah, dan bermanfaat. Sebagai contoh inovasi, melihat beberapa inovasi di video-video youtube dengan kata kunci "lifehack". Di video itu diperlihatkan bagaimana suatu produk yang sudah ada, kemudian di-inovasikan dan bisa menghasilkan sesuatu yang bernilai jual lebih tinggi dan lebih bermanfaat.

c. Penemuan (invention)

Istilah ini lebih menekankan pada menciptakan sesuatu yang belum pernah ada sebelumnya dan dapat diakui sebagai karya yang mempunyai fungsi yang unik atau belum pernah diketahui sebelumnya. Pembuatan aplikasi-aplikasi berbasis android dan iOS juga menjadi salah satu contoh penemuan yang berbasis teknologi dan informasi yang sangat memudahkan manusia dalam melakukan kegiatan sehari-hari.

Istilah Ekonomi Kreatif mulai ramai diperbincangkan sejak John Howkins, menulis buku "Creative Economy, How People Make Money from Ideas". Howkins menyatakan Ekonomi Kreatif sebagai kegiatan ekonomi dimana input dan outputnya adalah Gagasan. Atau dalam satu kalimat yang singkat, esensi dari kreativitas adalah gagasan. Maka dapat dibayangkan bahwa hanya dengan modal gagasan, seseorang yang kreatif dapat memperoleh penghasilan yang relatif tinggi.

Kondisi ekonomi yang diharapkan oleh Indonesia adalah ekonomi yang berkelanjutan dan juga memiliki beberapa sektor sebagai pilar maupun penopang kegiatan ekonomi di Indonesia. Keberlanjutan yang dimaksud adalah kemampuan untuk beradaptasi terhadap kondisi geografis dan tantangan ekonomi baru, yang pada akhirnya menghasilkan keberlanjutan pertumbuhan (sustainable growth).

Pertumbuhan yang tinggi tercermin dari kompetensi individu-individu dalam menciptakan inovasi. Ekonomi Kreatif yang di dalamnya terdapat industri-Industri kreatif memiliki daya tawar yang tinggi didalam ekonomi berkelanjutan karena individu-individunya memiliki modal kreativitas (creative capital) yang mereka gunakan untuk menciptakan inovasiinovasi.

Di Indonesia, yang dimaksud dengan kontribusi terhadap perekonomian antara lain sebagai berikut: Pertama, kontribusi terhadap Produk Domestik Bruto (PDB). Menurut data Badan Pusat Statistik (BPS) industri ini di Indonesia memberi kontribusi sebesar 7,28\% terhadap PDB pada tahun 2008 dan $7,8 \%$ terhadap PDB secara rata-rata dari tahun 2002 sampai 2008. Kontribusi industri kreatif terhadap PDB sebagian besar berasal dari lapangan usaha fashion $(3,7 \%)$ dan kerajinan $(1,9 \%)$.

Kedua, penciptaan lapangan pekerjaan, data dari BPS menunjukkan bahwa industri kreatif di Indonesia menyerap 7.686.410 tenaga kerja pada tahun 2008 dan rata-rata 7.391.642 tenaga kerja dari tahun 2002 sampai 2008. Secara rata-rata dari tahun 2002 sampai 2008, industri kreatif menyerap $7,7 \%$ total tenaga kerja di industri. Dengan persentase sebesar tersebut, industri kreatif merupakan industri kelima terbesar yang menyerap tenaga kerja setelah industri Pertanian, Peternakan, Kehutanan, dan Perikanan; Perdagangan, Hotel dan Restoran; Jasa 
Kemasyarakatan; dan Pengolahan.

Ketiga adalah peningkatan kegiatan ekspor. Dalam kurun waktu tahun 20082010, industri kreatif mencatatkan kontribusi net trade yang dominan dan selalu meningkat, berturut- turut sebesar $41,7 \%$, $54,7 \%, 57,8 \%$ dibandingkan dengan net trade nasional. Statistik ini menunjukkan bahwa industri kreatif merupakan salah satu penopang peningkatan pendapatan masyarakat. Dan sebagai salah satu sektor penyumbang devisa utama nasional, industri kreatif memiliki peran penting dalam terciptanya stabilitas moneter nasional.

Menurut UK Government Task Force yang disitasi oleh Jones et.al (2004) mengartikan industri kreatif sebagai berikut "those industries which have their origins in individual creativity, skill and talent and which have a potential for wealth and job creation through the generation and exploitation of intellectual property". Kemudian pengertian industri kreatif hampir sama dengan yang dirujuk oleh buku Pengembangan Ekonomi Kreatif Indonesia 2025: Rencana Pengembangan Ekonomi Kreatif Indonesia 2009-2015, yang diterbitkan oleh Kementrian Perdagangan RI, industri kreatif didefinisikan sebagai industri yang berasal dari pemanfaatan kreativitas, keterampilan serta bakat individu untuk menciptakan kesejahteraan serta lapangan pekerjaan dengan menghasilkan dan memberdayakan daya kreasi dan daya cipta individu tersebut.

Pemerintah Indonesia, dalam hal ini Kementrian Perdagangan RI, mengelompokkan 14 jenis industri ekonomi, yaitu: 1) Periklanan, 2) Arsitektur, 3) Pasar Barang Seni, 4) Kerajinan, 5) Desain, 6) Fesyen, 7) Video, Film, dan Fotografi, 8) Permainan Interaktif, 9) Musik, 10) Seni Pertunjukan, 11) Penerbitan dan Percetakan, 12) Layanan Komputer dan Piranti Lunak, 13) Televisi dan Radio, serta 14) Riset dan Pengembangan.

Klasifikasi 14 subsektor industri kreatif yang ada di Indonesia dibagi berdasarkan dua dimensi, yaitu: (a) substansi yang dominan dalam subsektor industri kreatif; (b) intensitas sumber daya yang dibutuhkan dalam subsektor industri kreatif. Kedua aspek dominan tersebut menentukan perkembangan industri kreatif.

\section{Substansi Dominan}

Substansi dominan pada suatu subsektor ekonomi dapat dibedakan menjadi empat aspek yang menjadi ciri-cirinya, yaitu:

a. Media

Pada subsektor ini, barang/jasa yang dihasilkan mengandalkan media untuk menampilkan kontennya sehingga dapat memberikan nilai tambah (value added).

b. Seni dan Budaya

Pada sub sektor ini, barang/jasa yang dihasilkan mengandalkan kandungan seni dan budaya yang terkandung di dalamnya sehingga dapat memberikan nilai tambah.

c. Desain

Pada sub sektor ini barang/jasa yang dihasilkan mengandalkan aspek perancangan/desain sehingga dapat memberikan nilai tambah.

d. Ilmu Pengetahuan dan Teknologi

Pada subsektor ini, barang/jasa yang dihasilkan mengandalkan penggunaan teknologi berbasis pengetahuan (knowledge) sebagai sarana penciptaannya sehingga dapat memberikan nilai tambah.

2. Intensitas Sumber Daya

Secara umum, industri kreatif menekankan pada kreativitas sebagai sumber daya utama. Tetapi, terdapat banyak industri yang membutuhkan sumber daya yang bersifat fisik, seperti penggunaan sumber daya alam. Misalnya saja pada industri fesyen, meskipun tren globalnya adalah pada peningkatan nilai tambah dari aspek desain, tetap saja industri ini memerlukan sumber daya alam berupa benang yang kemudian dijadikan kain sehingga produk yang dihasilkan nampak bentuk fisiknya. Contoh lainnya adalah industri kerajinan yang masih memerlukan bahan baku alam seperti kayu, rotan, batu-batuan, logam, dan lain sebagainya juga industri percetakan yang masih memerlukan kertas yang kesemuanya memerlukan bahan baku dari alam. 


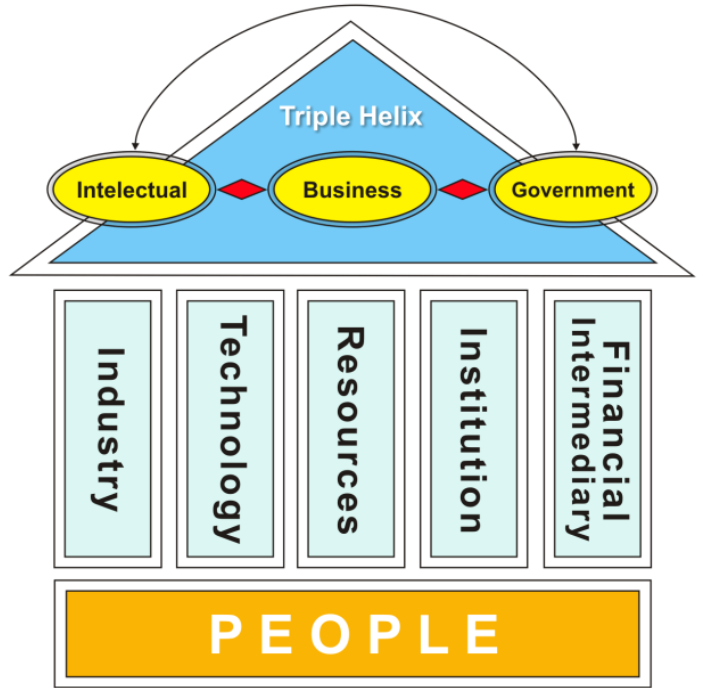

Gambar 1: Model Pengembangan Ekonomi Kreatif

Sumber: https://triplehelix.stanford.edu;

Seperti yang terlihat pada gambar di atas, bahwa yang menjadi pondasi dalam pengembangan ekonomi kreatif adalah sumber daya manusia (people). Keunikan dari industri kreatif adalah peran sumber daya manusia yang menjadi modal utama untuk membuat aktivitas ekonomi untuk menghasilkan satu industri baru. Human capital adalah aset yang paling berharga dalam perusahaan khususnya daya intelektual nya. Manusialah yang mengatur suatu perusahaan dan yang menyatakan nilai tambah. Dengan kata lain manusia khususnya kemampuan, kebijaksanaan, atau daya intelektualnya memiliki arti penting dan memiliki peranan yang sangat besar dalam mengelola suatu perusahaan.

\section{PEMBAHASAN}

Seiring dengan berkembangnya zaman sumber daya manusia tidak lagi berperan sebagai sumber daya pendukung melainkan sebagai modal suatu organisasi yang dikenal dengan sebutan human capital. Saat ini dalam mempertahankan keberadaan hidupnya yang sarat akan kompetisi, kinerja perusahaan tidak hanya diukur oleh financial return saja, tetpi juga harus mampu melipatgandakankannya untuk jangka panjang. Berdasarkan hal tersebut, maka pelipatgandaan kinerja perusahaan harus ditujukan pada kinerja human capital.
Terdapat beberapa pendapat mengenai definisi tentang human capital. Pengertian human capital yang dikutip oleh Al Ma'ni dan Jaradat (2010), diantaranya pendapat dari Al-Ali et.al (2006) human capital merupakan keseluruhan pengalaman dan pengetahuan, kemampuan, antusiasme, kreativitas dan kualitas yang dimiliki para karyawan pada sebuah organisasi; Yaseen (2007); kombinasi dari pengetahuan, pembelajaran, kompetensi inti para karyawan dalam rangka mencapai tujuan, programprogram di organisasi dan tugastugas fungsional mereka. Mc.Gregor et.al (2004) menyatakan bahwa human capital mencakup pertimbangan sumber daya manusia secara luas, yaitu sebagai tenaga kerja pada suatu perusahaan dan secara lebih spesifik, yaitu kompetensi individu dalam bentuk pengetahuan, skill, dan sifatsifat dari para manajer serta orang-orang yang diaturnya.

Berdasarkan beberapa pengertian di atas dapat disimpulkan bahwa human capital merupakan keterpaduan pengetahuan,pembelajaran, pengalaman, kompetensi inti, keterampilan, kemampuan yang harus dimiliki oleh setiap individu yang ada dalam suatu organisasi atau perusahaan yang akhirnya dapat meningkatkan produktivitas karyawan dan berimbas pada produktivitas perusahaan. Oleh karena itu, pendekatan sumber daya manusia sebagai human capital selaras dengan pengembangan ekonomi kreatif yang menitikberatkan pada manusia yang memiliki pengetahuan dan kreativitas.

\section{SIMPULAN}

Berdasarkan pembahasan diatas, dapat disimpulkan bahwa perkembangan teknologi informasi dan komunikasi memberikan kontribusi dan mendorong tumbuhnya ekonomi kreatif, yang dapat dijadikan sebagai salah satu solusi untuk mensejahterakan masyarakat karena dalam sistem ekonomi kreatif memberikan adanya nilai tambah baik kepada industrinya sendiri ataupun kepada sumber daya 
manusianya. Keberadaan ekonomi kreatif kreatif memberikan dampak positif dalam mengurangi tingkat pengangguran dan akhirnya akan meningkatkan tingkat perekonomian.

\section{DAFTAR RUJUKAN}

Afiff, Faisal. 2012. Pilar Pilar Ekonomi Kreatif. Artikel. Universitas Bina Nusantara: Jakarta.

Arief Johari, Globalisasi dan Dampak Desain Serta Relasinya Terhadap Industri Kreatif, Magister Desain ITB 27111006.

Buhler, P. (1999). Managing in the 90‘s: Training 90's style: An Organizational Requirement. National Research Bureau 60 (14).

Departemen Perdagangan Republik Indonesia: Pengembangan Ekonomi Kreatif Indonesia 2025: Rencana Pengembangan Ekonomi Kreatif Indonesia 2009-2015, Deperdag RI, 2009.

Department for Culture, Media, and Sport of the United Kingdom (DCMS UK). 2001. Creative Industries Mapping Document. London. http://www.idea.gov.uk/idk/core/pag e.do?pageId=11136366

Elka, Mari Pangestu. 2008. Pengembangan Ekonomi Kreatif Indonesia 2025. Cetak Biru Ekonomi Kreatif: Departemen Perdagangan Republik Indonesia.

Hawlett, R. (2002). Intergrating Human Capital Concepts in Productivity and Growth Topics. Journal of Management Research 2(1): 22-42.
Howkins, John. 2001. Creative Economy: How People Make Money from Ideas. London: Pinguin Global.

Jo Foord, 2008, Strategies for creative industries: an international review, Creative Industries Journal Volume 1 Number 2 Cities Institute, London Metropolitan University.

McGregor, J., Tweed, D., Pech, R. (2004). Human capital in the new economy: Devil's bargain? Journal of Intellectual Capital 5 (1): 153-164. 